\title{
The Determination of Benzo[a]Pyrene and Benz[a]Anthracene in Mainstream and Sidestream Smoke of the Kentucky Reference Cigarette 1R4F and a Cigarette Which Heats but Does Not Burn Tobacco: A Comparison*
}

by

Charles H. Risner,

\author{
R. J. Reynolds Tobacco Company, \\ Bowman Gray Technical Center, \\ Winston-Salem, North Carolina, U.S.A.
}

\section{SUMMARY}

A quantitative method for the determination of benz$[a]$ anthracene $(\mathrm{B}[a] \mathrm{A})$ and benzo $[a]$ pyrene $(\mathrm{B}[a] \mathrm{P})$ in mainstream and sidestream cigarette smoke by high performance liquid chromatography (HPLC) has been developed. Mainstream and sidestream particulate matter is collected on Cambridge filter pads. The polycyclic aromatic hydrocarbons (PAH) are extracted with cyclohexane and subjected to normal-phase chromatography to isolate target fractions which are concentrated and then diluted with acetonitrile or acetonitrile/water prior to reverse-phase analytical chromatography.

The Kentucky Reference cigarette 1R4F and a cigarette which heats but does not burn tobacco (New Cigarette) developed at R. J. Reynolds Tobacco Company were analyzed and compared with respect to $\mathrm{B}[a] \mathrm{P}$ and $\mathrm{B}[a] \mathrm{A}$ in both mainstream and sidestream smoke.

\section{ZUSAMMENFASSUNG}

Es wurde eine Methode zur quantitativen Bestimmung von Benz[a]anthracen $(\mathrm{B}[a] \mathrm{A})$ und Benzo[a]pyren $(\mathrm{B}[a] \mathrm{P})$ im Haupt- und Nebenstromrauch von Zigaretten durch Hochleistungsflüssigkeits-Chromatographie (HPLC) entwickelt. Die Partikelphase des Haupt- und Nebenstromrauchs wurde mit Cambridge-Filtern gesammelt. Die polyzyklischen aromatischen Kohlenwasserstoffe $(\mathrm{PAH})$ wurden mit Cyclohexan extrahiert und einer konventionellen Säulenchromatographie unterwor-

${ }^{2}$ Received: 13th April 1989 - accepted: 6th September 1989. fen. So wurden bestimmte Fraktionen isoliert, die konzentriert und dann in Acetonitril oder einem Acetonitril/ Wassergemisch gelöst wurden; anschließend wurde eine analytische Umkehrphasen-Chromatographie durchgeführt.

Die Kentucky-Referenz-Cigarette 1R4F und eine Cigarette, die den Tabak zwar erhitzt aber nicht verbrennt (Neue Cigarette, sie wurde bei R. J. Reynolds entwickelt), wurden analysiert und in ihrem Gehalt an $\mathrm{B}[a] \mathrm{P}$ und $\mathrm{B}[a] \mathrm{A}$ im Haupt- und Nebenstromrauch miteinander verglichen.

\section{RESUME}

On a développé une méthode quantitative pour déterminer au moyen de chromatographie liquide à haute pression les substances benz $[a]$ anthracène $(\mathrm{B}[a] \mathrm{A})$ et benzo $[a]$ pyrène $(\mathrm{B}[a] \mathrm{P})$ contenues dans le courant principal et secondaire de la fumée de cigarette. La phase particulaire de la fumée du courant principal et secondaire a été collectée sur filtres Cambridge. Les hydrocarbures aromatiques polynucléaires ont été extraits à l'aide de cyclohexane et isolés sur chromatographie en phase normale. Avant l'analyse par chromatographie en phase inverse les fractions ont été concentrées et puis diluées dans de l'acétonitrile ou un mélange d'acétonitrile et d'eau. L'analyse du contenu en $\mathrm{B}[a] \mathrm{P}$ et $(\mathrm{B}[a] \mathrm{A})$ dans la fumée du courant principal et secondaire a été réalisée d'une part sur la cigarette référence de Kentucky $1 \mathrm{R} 4 \mathrm{~F}$ et d'autre part sur une cigarette qui chauffe mais ne brûle pas le tabac (cigarette nouvelle, développée chez R. J. Reynolds Tobacco Company). 


\section{INTRODUCTION}

Many methods applying various analytical techniques have been developed for the determination of polycyclic aromatic hydrocarbons (PAH) in cigarette smoke condensate. These techniques include high performance liquid chromatography (HPLC) (1-6), gas chromatography (7-14), thin-layer chromatography $(15,16)$, paper chromatography (17) and spectrophotometry (15, 18-21). Many of these procedures require either a large sample or an extensive sample preparation procedure and are directed exclusively at the determination of benzo[a]pyrene $(\mathrm{B}[\mathrm{a}] \mathrm{P})$ in mainstream cigarette smoke. Frequently, $\mathrm{B}[a] \mathrm{P}$ has been used as an indicator for the entire compound class.

Little work has been done to quantify PAH's other than $\mathrm{B}[\mathrm{a}] \mathrm{P}$ in tobacco smoke (either mainstream or sidestream) by HPLC. At this time, HPLC coupled with fluorescence detection appears to be the method of choice for these non-volatile compounds $(1-4,6)$. To follow the distribution and quantity of PAH's in smoke condensate, two PAH's with different structures, $\mathrm{B}[a] \mathrm{A}$ and $\mathrm{B}[a] \mathrm{P}$, were monitored. This provides a more complete picture with respect to the overall class.

\section{EXPERIMENTAL}

\section{A. Apparatus for Preparative Liquid Chromatography and Reagents}

1. Isolation/preparation of the Cambridge pad extract of the cigarette smoke condensate for $\mathrm{B}[a] \mathrm{P}$ and $\mathrm{B}[a] \mathrm{A}$ was performed on a Waters Associates liquid chromatograph equipped with a single Model 6000A pump. Detection was accomplished by means of a Waters Model 420 fluorescence detector equipped with a G4T5 mercury lamp, $254 \mathrm{~nm}$ excitation band-pass filter and $375 \mathrm{~nm}$ emission long-pass filter. Sample extracts were injected via a Model U6K injector equipped with a $1000 \mu \mathrm{l}$ sample loop. All detector outputs were monitored via a Model 730 module and data were acquired on-line by a computer (Hewlett-Packard RTE 1000 and Beckman Computer Automated Laboratory System).

2. A Waters Radial-Pak $\mu$ Bondapak- $\mathrm{NH}_{2}, 8 \mathrm{~mm} \times 10 \mathrm{~cm}$, $10 \mu \mathrm{m}$ particle size column was used at ambient temperature in a Waters Z-module.

3. $\mathrm{B}[a] \mathrm{P}$ and $\mathrm{B}[a] \mathrm{A}$ (Aldrich) and all solvents (Burdick and Jackson) were obtained and used as received. Distilled water was further purified by passage through a Barnstead Nanopure System.

\section{B. Smoke Collection and Cigarettes}

Mainstream and sidestream cigarette smoke particulate matter was collected on Cambridge filter pads by pro- cedures described by Pillsbury et al. (22) and Johnson (23), respectively. Reference cigarettes 1R4F were obtained from the Tobacco and Heath Research Institute, Lexington, Kentucky. The New Cigarette was obtained in-house and has been described elsewhere (24).

\section{Apparatus for Analytical Liquid Chromatography}

1. The analytical determination of $\mathrm{B}[a] \mathrm{P}$ and $\mathrm{B}[a] \mathrm{A}$ was done on a seperate Waters liquid chromatograph consisting of two Model 6000A pumps, a Perkin-Elmer 650-10S fluorescence detector and a WISP 710B autosampler with an injection volume of $200 \mu \mathrm{l}$.

2. The analytical column was a Vydac 201TP54, $4.6 \mathrm{~mm} \times 250 \mathrm{~mm}, 5 \mu \mathrm{m}$ particle size, polymeric octadecylsilane on silica (The Separations Group).

\section{Analytical Procedure: Normal-Phase Chromatog- raphy}

The normal-phase isolation/preparation of $\mathrm{B}[a] \mathrm{A}$ was similar to that for $\mathrm{B}[a] \mathrm{P}$ described elsewhere (1). $\mathrm{B}[a] \mathrm{A}$ has one less aromatic ring than $\mathrm{B}[a] \mathrm{P}$ and therefore elutes in an earlier fraction that contained mostly isomers of the same ring number. Attempts to isolate both $\mathrm{B}[a] \mathrm{A}$ and $\mathrm{B}[\mathrm{a}] \mathrm{P}$ in a single fraction of $1 \mathrm{R} 4 \mathrm{~F}$ condensate were not successful.

\section{E. Analytical Procedure: Reverse-Phase Chromatog- raphy}

The conditions and procedures for the determination of $\mathrm{B}[\mathrm{a}] \mathrm{P}$ have been described previously (1). In order to determine the optimum excitation and emission wavelength settings for the detection of $\mathrm{B}[\mathrm{a}] \mathrm{A}$, fluorescence spectra of $\mathrm{B}[a] \mathrm{A}$ in acetonitrile $(\mathrm{ACN})$ were obtained. Data in Table 1 show the wavelength maxima obtained with the more prominent wavelengths in bold type. Combinations of these wavelength sets were evaluated on the detector at a constant standard concentration so that the most sensitive (highest response) set of wavelengths could be determined. The exitation wavelength of $287 \mathrm{~nm}$ and emission wavelength of $409 \mathrm{~nm}$ were the most responsive and probably the most selective under sample chromatographic conditions (see below).

Table 1.

Excitation and emission wavelengths for B[a]A.

\begin{tabular}{l|l}
\hline & Wavelength $(\mathrm{nm})^{\mathrm{a}}$ \\
\hline Excitation & $287,328,340,358$ \\
Emission & $385,409,432,464$ \\
\hline
\end{tabular}

a - more prominent wavelengths in bold type 
Table 2.

Gradient conditions for the separation of $\mathrm{B}[\mathrm{a}] \mathrm{A}$ from crysene (flow rate at $1.5 \mathrm{ml} / \mathrm{min}$ ).

\begin{tabular}{c|c|c}
\hline Time (min.) & \% Acetonitrile & \% Water \\
\hline 0 & 45 & 55 \\
20 & 45 & 55 \\
50 & 95 & 5 \\
60 & 95 & 5 \\
64 & 45 & 55 \\
84 & 45 & 55 \\
\hline
\end{tabular}

Since other 4-ring compounds are present in tobacco smoke $(5,8,10,11,17)$, e.g., chrysene, the analytical column was evaluated with respect to the separation of the $\mathrm{B}[\mathrm{a}] \mathrm{A}$-chrysene pair. Isocratic conditions were of little value for separating this pair. Data in Table 2 show the linear gradient that was most effective in separating the $\mathrm{B}[\mathrm{a}] \mathrm{A}-\mathrm{chrysene}$ pair. The gradient included a column cleaning segment ( $95 \%$ acetonitrile for 10 minutes) to help prevent excessive buildup of strongly retained sample components. Note that there are two twenty-minute segments for column equilibrium prior to the next injection. These longer equilibrium conditions helped to minimize the "degassing" which occurred at these mixtures of acetonitrile and water. Figure 1 illustrates the resolution obtained between $\mathrm{B}[a] \mathrm{A}$ and chrysene with the described gradient. $\mathrm{B}[a] \mathrm{A}$ had a significantly greater response factor than chrysene at these wavelengths which showed the selectivity that can be attained by fluorescene detection. The standards used in Figure 1 were dissolved in $1: 1$, acetonitrile/water. Attempts to chromatograph these compounds in 100 percent acetonitrile resulted in a

Figure 1.

B[a]A - Chrysene Separation. Conditions: Vydac 201TP54 $(4.6 \mathrm{~mm} \times 250 \mathrm{~mm}, 5 \mu \mathrm{m})$; acetonitrile/water, $45: 55$ initially for 20 minutes to $95: 5$ over 30 minutes with linear gradient at $1.5 \mathrm{ml} / \mathrm{min}$.; injection volume, $200 \mu \mathrm{l}$; fluorescence detection, $287 \mathrm{~nm}$ excitation, $409 \mathrm{~nm}$ emission; B[a]A, $8.3 \mathrm{ng} / \mathrm{ml}$, chrysene, $276 \mathrm{ng} / \mathrm{ml}$ in 1:1, acetonitrile/water.

\section{Figure 1.}

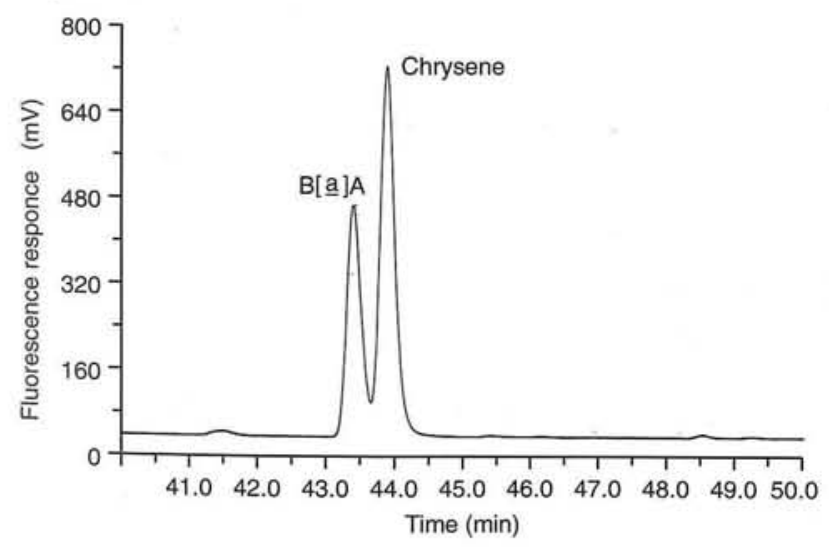

Table 3.

Linear correlation of chromatographic system for B[a]P.

\begin{tabular}{c|c|c|c}
\hline \multicolumn{2}{c|}{ 1R4F Range } & \multicolumn{2}{c}{ New Cigarette Range } \\
\hline $\begin{array}{c}\text { Standard } \\
(\mathrm{ng} / \mathrm{ml})\end{array}$ & $\begin{array}{c}\text { Height } \\
(\mathrm{mV})\end{array}$ & $\begin{array}{c}\text { Standard } \\
(\mathrm{ng} / \mathrm{ml})\end{array}$ & $\begin{array}{c}\text { Height } \\
(\mathrm{mV})\end{array}$ \\
\hline 1.4 & 70.7 & 0.042 & 42.8 \\
2.8 & 135.8 & 0.084 & 63.4 \\
4.2 & 213.4 & 0.210 & 141.0 \\
5.6 & 289.2 & 0.420 & 238.3 \\
8.4 & 436.3 & 0.840 & 447.3 \\
14.0 & 714.2 & 1.050 & 544.2 \\
\hline
\end{tabular}

$R^{2}=0.9996$

$\mathrm{R}^{2}=0.9991$

Table 4.

Linear correlation of chromatographic system for B[a]A.

\begin{tabular}{c|c|c|c}
\hline \multicolumn{2}{c|}{ 1R4F Range } & \multicolumn{2}{c}{ New Cigarette Range } \\
\hline $\begin{array}{c}\text { Standard } \\
(\mathrm{ng} / \mathrm{ml})\end{array}$ & $\begin{array}{c}\text { Height } \\
(\mathrm{mV})\end{array}$ & $\begin{array}{c}\text { Standard } \\
(\mathrm{ng} / \mathrm{ml})\end{array}$ & $\begin{array}{c}\text { Height } \\
(\mathrm{mV})\end{array}$ \\
\hline 1.30 & 43.7 & 0.052 & 24.2 \\
2.60 & 88.9 & 0.104 & 35.6 \\
5.20 & 176.0 & 0.260 & 85.7 \\
6.50 & 222.2 & 0.416 & 130.0 \\
9.75 & 324.8 & 0.780 & 247.6 \\
13.00 & 448.2 & 1.040 & 373.3 \\
\hline
\end{tabular}

$R^{2}=0.9992$

$R^{2}=0.9908$

single peak. Resolution can only be achieved when the samples are dissolved in a solvent similar in composition to the mobile phase.

Linearity of detector response in the appropriate ranges for the two cigarettes are given in Tables 3 and 4 for $\mathrm{B}[a] \mathrm{P}$ and $\mathrm{B}[a] \mathrm{A}$, respectively.

\section{F. Sample Preparation}

For the determination of $\mathrm{B}[a] \mathrm{A}$ and $\mathrm{B}[a] \mathrm{P}$ in mainstream smoke condensate of $1 \mathrm{R} 4 \mathrm{~F}$, five cigarettes were smoked; for the New Cigarette, twenty cigarettes were smoked. The wet total particulate matter (WTPM) is recorded and the Cambridge pad, in both cases, was extracted for one hour by wrist-action shaking of the pad in $10 \mathrm{ml}$ of cyclohexane.

For sidestream smoke condensate, two Kentucky Reference $1 \mathrm{R} 4 \mathrm{~F}$ cigarettes and six New Cigarettes were used. The 1R4F pad was extracted with a total of $50 \mathrm{ml}$ of cyclohexane, $10 \mathrm{ml}$ being used to rinse the hood, and similarly, the New Cigarette Cambridge pad was extracted with a total of $20 \mathrm{ml}$ cyclohexane. These samples also were shaken one hour. Standards in cyclohexane 
were injected $(1 \mathrm{ml})$ onto the normal-phase, $\mathrm{NH}_{2}$ column with hexane as the mobile phase at a flow of $2 \mathrm{ml} / \mathrm{min}$. Only when there was a steady baseline and at least two identical chromatograms of the standard were attained, was the sample extract injected. The sample fraction corresponding to 2 minutes prior to the standard peak elution threshold time until 2 minutes following complete elution of the standard was collected in a $25-\mathrm{ml}$ collection tube. The collected $\mathrm{B}[a] \mathrm{A}$ fraction in hexane (usually ca. $14 \mathrm{ml}$ ) was heated at $50^{\circ} \mathrm{C}$ under nitrogen until the hexane was completely evaporated. Prior to the following analytical determination, $1 \mathrm{ml}$ of $1: 1$, acetonitrile/water was used to dissolve the residue.

A variety of blank determinations also were done as described above. For mainstream and sidestream smoke, the same number of unlit cigarettes were subjected to the same conditions as the lit cigarette samples, simultaneously, while the sample cigarettes were being smoked. Also, in the case of sidestream and mainstream smoke from 1R4F, a backup Cambridge pad was used to determine if the initial pad became overloaded. The cyclohexane solvent also was analyzed for $\mathrm{B}[a] \mathrm{A}$ and $\mathrm{B}[a] \mathrm{P}$.

Table 5.

Precision for the determination of $\mathrm{B}[\mathrm{a}] \mathrm{P}$ in $1 \mathrm{R} 4 \mathrm{~F}$ reference cigarette and the New Cigarette.

\begin{tabular}{c|c|c}
\hline \multicolumn{3}{|c}{ 1R4F Cigarette } \\
\hline \multirow{2}{*}{$\begin{array}{c}\text { Chromatographic } \\
\text { (Height) }^{\mathrm{a}}\end{array}$} & \multicolumn{2}{|c}{ Overall (ng/cigarette) } \\
\cline { 2 - 3 } 2 & Mainstream $^{\mathrm{b}}$ & Sidestream $^{\mathrm{c}}$ \\
\hline 218.1 & 9.66 & 161.6 \\
215.2 & 9.51 & 145.6 \\
210.2 & 10.62 & 136.8 \\
206.8 & 8.66 & 138.2 \\
204.6 & 8.98 & 149.7 \\
205.6 & 7.78 & 155.8 \\
Mean 210.0 & 9.20 & 148.0 \\
Std. dev. 5.5 & 0.96 & 9.8 \\
\% RSD 2.6 & 10.43 & 6.6 \\
\hline
\end{tabular}

\begin{tabular}{c|c|c}
\hline \multicolumn{3}{|c}{ New Cigarette } \\
\hline \multirow{2}{*}{$\begin{array}{c}\text { Chromatographic } \\
\text { (Height) }^{\mathrm{d}}\end{array}$} & Overall (ng/cigarette) \\
\cline { 2 - 3 } & Mainstream $^{\mathrm{e}}$ & Sidestream $^{\mathrm{f}}$ \\
\hline 128.0 & 0.08 & 2.69 \\
132.4 & 0.06 & 2.54 \\
131.8 & 0.08 & 3.00 \\
125.7 & 0.06 & 3.84 \\
134.4 & 0.09 & 4.46 \\
126.8 & 0.08 & 2.04 \\
Mean 129.8 & 0.08 & 3.10 \\
Std. dev. 3.4 & 0.01 & 0.90 \\
\% RSD 2.6 & 12.50 & 29.03 \\
\hline
\end{tabular}

a $-4.20 \mathrm{ng} \mathrm{ml}^{-1}$ standard

b -5 cigaretes, $10 \mathrm{ml}$ cyclohexane extract

c -2 cigarettes, total of $50 \mathrm{ml}$ cyclohexane d $-0.21 \mathrm{ng} \mathrm{ml}^{-1}$ standard

e -20 cigarettes, $10 \mathrm{ml}$ cyclohexane extract

f -6 cigarettes, total of $20 \mathrm{ml}$ cyclohexane
Table 6.

Precision for the determination of $\mathrm{B}[\mathrm{a}] \mathrm{A}$ in $1 \mathrm{R} 4 \mathrm{~F}$ reference cigarette and the New Cigarette.

\begin{tabular}{|c|c|c|}
\hline \multicolumn{3}{|c|}{ 1R4F Cigarette } \\
\hline \multirow{2}{*}{$\begin{array}{c}\text { Chromatographic } \\
{\text { (Height })^{\mathrm{a}}}^{\text {Cheic }}\end{array}$} & \multicolumn{2}{|c|}{ Overall (ng/cigarette) } \\
\hline & Mainstream ${ }^{b}$ & Sidestream $^{\circ}$ \\
\hline 185.8 & 9.6 & 249.6 \\
\hline 188.5 & 12.3 & 198.5 \\
\hline 184.6 & 10.6 & 186.0 \\
\hline 184.4 & 10.8 & 184.0 \\
\hline 181.4 & 8.6 & 170.5 \\
\hline 181.8 & 11.4 & 326.0 \\
\hline Mean 184.4 & 10.5 & 219.1 \\
\hline Std. dev. 2.6 & 1.3 & 59.1 \\
\hline$\%$ RSD $\quad 1.4$ & 12.3 & 27.0 \\
\hline
\end{tabular}

\begin{tabular}{c|c|c}
\hline \multicolumn{3}{c}{ New Cigarette } \\
\hline \multirow{2}{*}{$\begin{array}{c}\text { Chromatographic } \\
\text { (Height) }^{\mathrm{d}}\end{array}$} & Overall (ng/cigarette) \\
\cline { 2 - 3 } & Mainstream $^{\mathrm{e}}$ & Sidestream $^{\dagger}$ \\
\hline 89.2 & 0.12 & 6.00 \\
84.6 & 0.12 & 7.92 \\
82.4 & 0.05 & 7.13 \\
86.7 & 0.08 & 12.03 \\
87.4 & 0.10 & 11.28 \\
90.2 & 0.12 & 7.45 \\
Mean 86.8 & 0.10 & 8.64 \\
Std. dev. 2.8 & 0.02 & 2.43 \\
\% RSD 3.2 & 20.00 & 28.12 \\
\hline
\end{tabular}

\begin{tabular}{|c|c|}
\hline $\begin{array}{l}\text { a }-5.20 \mathrm{ng} \mathrm{ml}^{-1} \text { standard } \\
\text { b }-5 \text { cigarettes, } \\
10 \mathrm{ml} \text { cyclohexane extract } \\
\text { - } 2 \text { cigarettes, } \\
\text { total of } 50 \mathrm{ml} \text { cyclohexane }\end{array}$ & $\begin{array}{l}\text { d }-0.26 \mathrm{ng} \mathrm{ml}^{-1} \text { standard } \\
\text { e }-20 \text { cigarettes, } \\
10 \text { ml cyclohexane extract } \\
\text { - } 6 \text { cigarettes, } \\
\text { total of } 20 \mathrm{ml} \text { cyclohexane }\end{array}$ \\
\hline
\end{tabular}

\section{RESULTS AND DISCUSSIONS}

Data in Tables 5 and 6 show both the instrumental and overall method precision for the determination of $\mathrm{B}[\mathrm{a}] \mathrm{A}$ and $\mathrm{B}[\mathrm{a}] \mathrm{P}$ in mainstream and sidestream smoke condensate of the Kentucky Reference 1R4F and the New Cigarette. As can be seen, the New Cigarette contained significantly less of these compounds than the $1 \mathrm{R} 4 \mathrm{~F}$ reference cigarette. Note that the \% RSD for the New Cigarette was higher than that of 1R4F. This difference may be attributed to the small quantities involved and the higher sensitivity levels required to determine these small amounts.

Data in Table 7 show the percent recovery of $\mathrm{B}[\mathrm{a}] \mathrm{P}$ and $\mathrm{B}[\mathrm{a}] \mathrm{A}$ from the mainstream smoke condensate of the New Cigarette extracted from a Cambridge pad. In order to determine the reason for these low recoveries for $\mathrm{B}[a] \mathrm{P}$, standards in cyclohexane were taken through the preparative system and evaluated versus a similar standard run through the analytical system. Results showed that the standard in cyclohexane is only ninety percent recovered 
Table 7.

Recovery/standard addition for $\mathrm{B}[\mathrm{a}] \mathrm{P}$ and $\mathrm{B}[\mathrm{a}] \mathrm{A}$ from the New Cigarette mainstream smoke.

\begin{tabular}{|c|c|c|c|}
\hline \multicolumn{4}{|c|}{$\mathrm{B}[\mathrm{a}] \mathrm{P}$} \\
\hline ng Added & ng Found & ng Recovered & $\%$ Recovery \\
\hline \multicolumn{2}{|l|}{0.00} & - & - \\
\hline 1.50 & 2.90 & 1.36 & 90.66 \\
\hline 3.00 & 4.23 & 2.69 & 89.66 \\
\hline 4.50 & 5.08 & 3.54 & 78.66 \\
\hline 6.00 & 6.51 & 4.97 & 82.83 \\
\hline \multicolumn{4}{|c|}{ Mean $=85.45$} \\
\hline \multicolumn{4}{|c|}{ Std. dev. $=5.71$} \\
\hline \multicolumn{4}{|c|}{$\%$ RSD $=6.68$} \\
\hline \multicolumn{4}{|c|}{$\mathrm{B}[\mathrm{a}] \mathrm{A}$} \\
\hline ng Added & $\mathrm{ng}$ Found & ng Recovered & $\%$ Recovery \\
\hline 0.00 & 2.50 & - & - \\
\hline 1.25 & 3.98 & 1.48 & 118.40 \\
\hline 2.50 & 5.08 & 2.58 & 103.20 \\
\hline 3.75 & 6.22 & 3.72 & 99.20 \\
\hline 5.00 & 7.66 & 5.16 & 103.20 \\
\hline \\
\hline \multicolumn{4}{|c|}{$\begin{array}{l}\text { Mean }=106.00 \\
\text { Std. dev. }=8.48\end{array}$} \\
\hline$\%$ RSD $=$ & .00 & & \\
\hline
\end{tabular}

from the preparative system. This result may explain the lower overall recovery for $\mathrm{B}[a] \mathrm{P}$. The $y$-intercepts obtained from the data in Table 7 yield results practically identical to those obtained by external standard, 0.08 versus $0.08 \mathrm{ng} /$ cigarettes for $\mathrm{B}[a] \mathrm{P}$ and 0.12 versus $0.10 \mathrm{ng} /$ cigarettes for $\mathrm{B}[\mathrm{a}] \mathrm{A}$.

Figures 2 and 3 show preparative chromatograms of the cyclohexane extracts of mainstream and sidestream smoke condensate. Efforts were made to isolate both $\mathrm{B}[a] \mathrm{A}$ and $\mathrm{B}[a] \mathrm{P}$ from a single 1-ml injection of the $1 \mathrm{R} 4 \mathrm{~F}$ cyclohexane extract. However, it appears that too much material was collected from the normal-phase system as indicated by the number of interfering compounds in the reverse-phase chromatograms. Further studies might make it possible to isolate both $\mathrm{B}[a] \mathrm{A}$ and $\mathrm{B}[a] \mathrm{P}$ from a single injection of the New Cigarette condensate. However, this single step isolation of $\mathrm{B}[\mathrm{a}] \mathrm{A}$ and $\mathrm{B}[\mathrm{a}] \mathrm{P}$ was not done since a time-wavelength programmable fluorescence detector was not available. As can be seen from Figures 2 and 3, the material extracted from the New Cigarette smoke condensate under these conditions appeared to be less complicated than that of 1R4F. However, there were greater amounts of PAH's in the sidestream than mainstream smoke of both cigarettes. These conclusions are supported by the results of other workers (25). Fractions were collected from normal-phase sample injections based on the predetermined retention time of standards in cyclohexane and subjected to reverse-phase chromatography, Figures 4-7. As indicated by the $\mu$-axis scale, larger amounts of $\mathrm{B}[a] \mathrm{A}$ and $\mathrm{B}[a] \mathrm{P}$ were observed in sidestream smoke compared to mainstream smoke. Smoke from the
Figure 2.

Normal-phase HPLC preparation of $1 \mathrm{R} 4 \mathrm{~F}$ and the New Cigarette mainstream smoke. Conditions: Waters $\mu$ Bondapak $\mathrm{NH}_{2}(8 \mathrm{~mm} \times 100 \mathrm{~mm}, 10 \mu \mathrm{m})$; hexane eluent, $2 \mathrm{ml} / \mathrm{min}$.; injection volume, $1 \mathrm{ml}$; fluorescence detection, $254 \mathrm{~nm}$ excitation, $375 \mathrm{~nm}$ emission. $a=1 \mathrm{R} 4 \mathrm{~F}$ ( $10 \mathrm{ml}$ cyclohexane, 5 cigarettes per pad); $b=$ New Cigarette $(10 \mathrm{ml}$ cyclohexane, 20 cigarettes per pad).

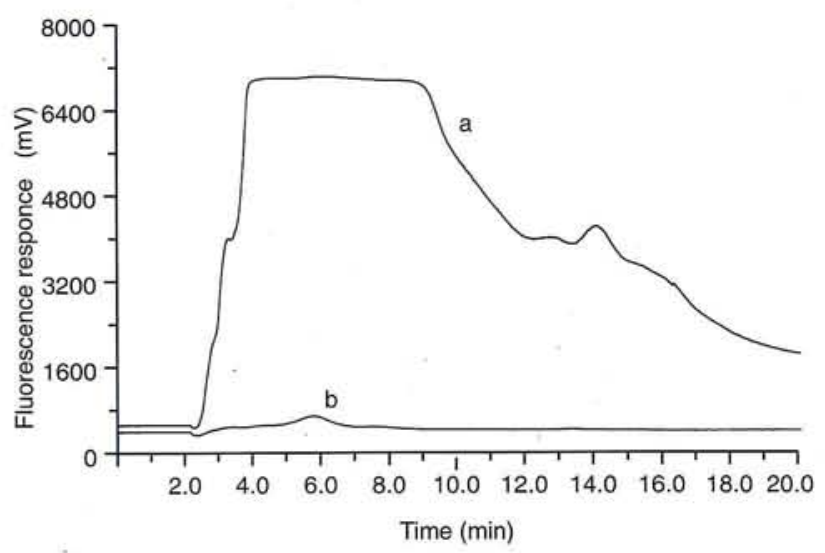

Figure 3 .

Normal-phase HPLC preparation of 1R4F and the New Cigarette sidestream smoke. Conditions: same as Figure 2. $a=1 \mathrm{R} 4 \mathrm{~F}$ ( $50 \mathrm{ml}$ cyclohexane, 2 cigarettes); $b=$ New Cigarette ( $20 \mathrm{ml}$ cyclohexane, 6 cigarettes).

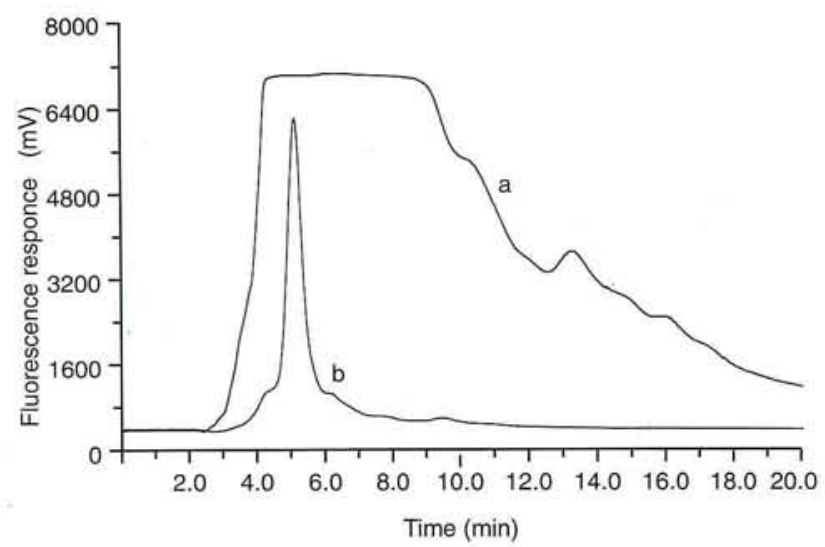

New Cigarette contained less $\mathrm{B}[a] \mathrm{A}$ and $\mathrm{B}[\mathrm{a}] \mathrm{P}$ than the 1R4F reference under these conditions. Results shown in Tables 5 and 6 indicate a hundred-fold reduction of $\mathrm{B}[a] \mathrm{P}$ and $\mathrm{B}[\mathrm{a}] \mathrm{A}$ in mainstream smoke for the New Cigarette compared to $1 \mathrm{R} 4 \mathrm{~F}$, a fifty-fold reduction of $\mathrm{B}[\mathrm{a}] \mathrm{P}$ and a twenty-five fold reduction of $\mathrm{B}[a] \mathrm{A}$ in sidestream smoke. It is obvious from the chromatography (both preparative and analytical) that the sample matrices for these two cigarettes are different.

Since PAH's are ubiquitous and the amounts in cigarette smoke are low and, therefore, susceptible to contamination, a variety of blank determinations were done. PAH's in the cyclohexane solvent and mainstream unlit cigarette blanks were usually below detection limits $(<0.01 \mathrm{ng} /$ cigarette for both $\mathrm{B}[a] \mathrm{P}$ and $\mathrm{B}[a] \mathrm{A})$. However, main- 
Figure 4.

Reverse-phase HPLC analytical determination of B[a]P in 1R4F and the New Cigarette mainstream smoke. Conditions: Vydac 201TP54 (4.6 $\times 250 \mathrm{~mm}, 5 \mu \mathrm{m})$; acetonitrile/water, 90:10 at $1 \mathrm{ml} / \mathrm{min}$; injection volume, $200 \mu \mathrm{l}$; fluorescence detection, $378 \mathrm{~nm}$ excitation, $405 \mathrm{~nm}$ emission. $a=1 \mathrm{R} 4 \mathrm{~F} ; \mathrm{b}=$ New Cigarette.

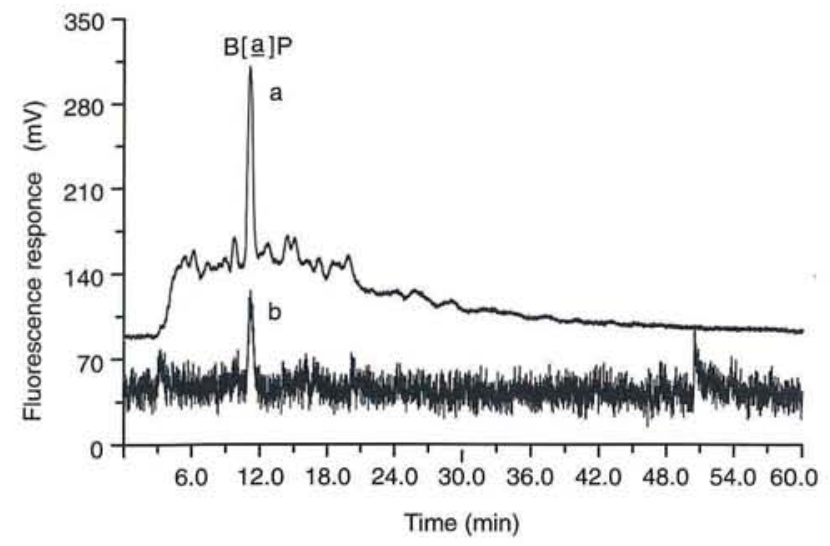

Figure 5.

Reverse-phase HPLC analytical determination of $\mathrm{B}[\mathrm{a}] \mathrm{P}$ in 1R4F and the New Cigarette sidestream smoke. Conditions: same as Figure 4. $a=1 R 4 F ; b=N e w$ Cigarette.

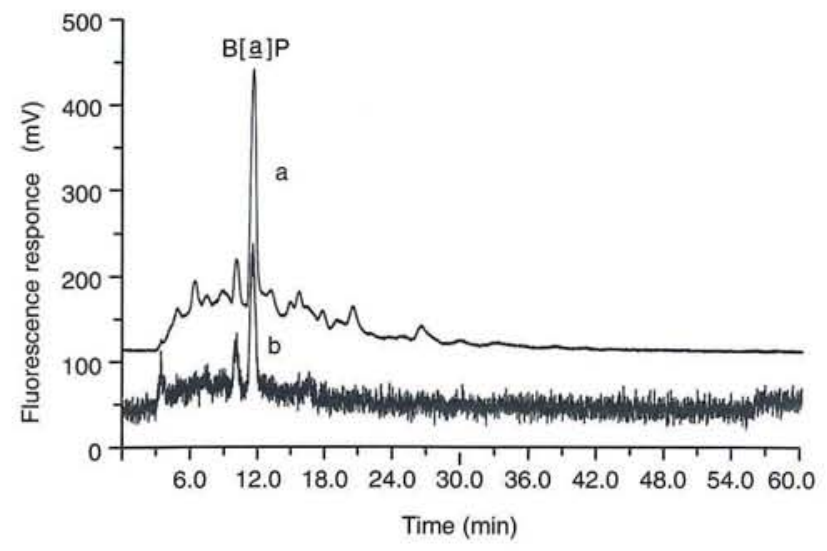

Figure 6.

Reverse-phase HPLC analytical determination of B[a]A in 1R4F and the New Cigarette mainstream smoke. Conditions: same as Figure 1. $a=1 R 4 F ; b=$ New Cigarette.

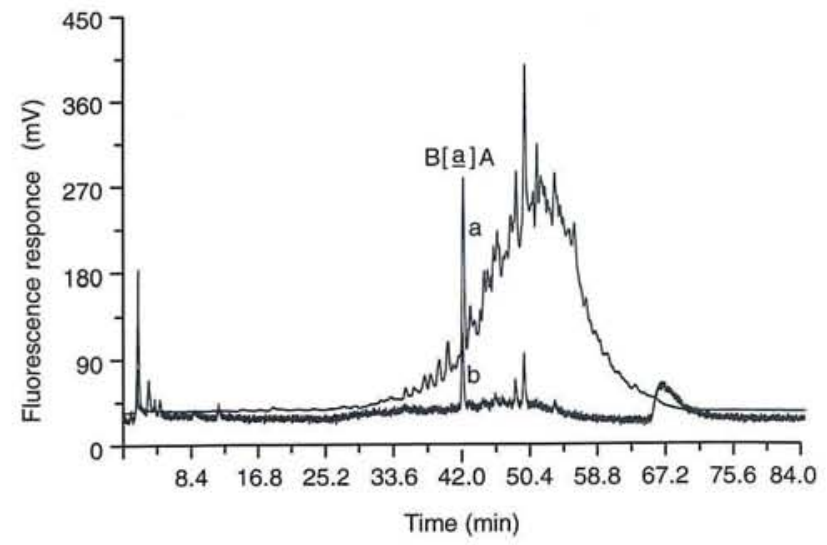

Figure 7.

Reverse-phase HPLC analytical determination of B[a]A in 1R4F and the New Cigarette sidestream smoke. Conditions: same as Figure 1. $a=1 \mathrm{R} 4 \mathrm{~F} ; \mathrm{b}=$ New Cigarette.

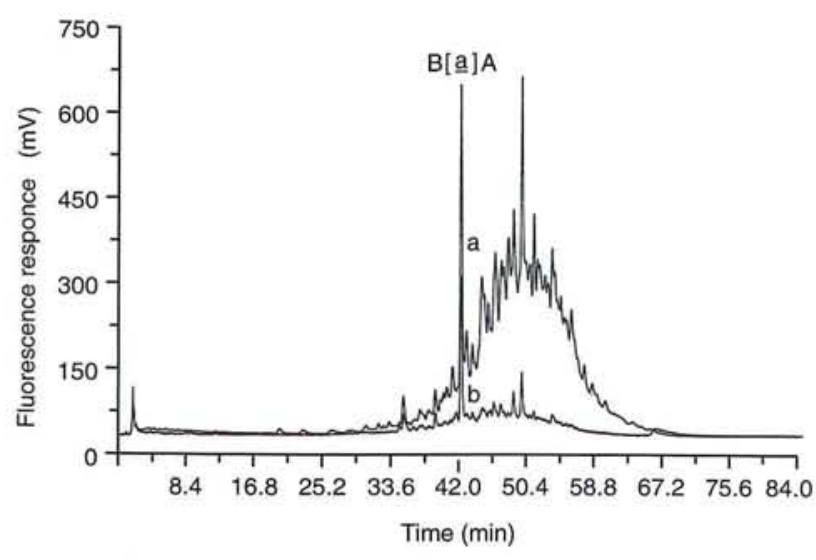

stream and sidestream backup pad(s) - a pad in a Cambridge holder situated in-line behind the primary collection pad - from the smoking of $1 \mathrm{R} 4 \mathrm{~F}$ and the New Cigarette did contain detectable amounts of both $\mathrm{B}[\mathrm{a}] \mathrm{P}$ and $\mathrm{B}[\mathrm{a}] \mathrm{A}$. The sidestream backup pad contained more than the mainstream and $\mathrm{B}[a] \mathrm{A}$ was present in a greater amount than $\mathrm{B}[a] \mathrm{P}$. The presence of more $\mathrm{B}[\mathrm{a}] \mathrm{A}$ may be attributed to its higher volatility versus $\mathrm{B}[a] \mathrm{P}$ and/or the large volume of air (which itself may contain $\mathrm{B}[a] \mathrm{A}$ ) passed through the system during sidestream smoke collection. These conclusions are supported by the significant amount of $\mathrm{B}[a] \mathrm{A}(0.24 \mathrm{ng} /$ cigarette $)$ found in unlit cigarette blanks under sidestream smoking and collection conditions.

\section{CONCLUSION}

A method has been described for the determination of $\mathrm{B}[\mathrm{a}] \mathrm{A}$ in cigarette smoke which is both accurate and precise in the ranges to which it was applied. Both sidestream and mainstream smoke can be analyzed for $\mathrm{B}[\mathrm{a}] \mathrm{A}$ by this procedure and, with a slight modification of the technique, for $\mathrm{B}[a[\mathrm{P}$. The results for the New Cigarette show a substantial reduction of these compounds in smoke when compared to the Kentucky Reference cigarette $1 \mathrm{R} 4 \mathrm{~F}$.

\section{REFERENCES}

1. Risner, C. H.: The determination of benzo[a]pyrene in the total particulate matter of cigarette smoke; J. Chrom. Sci. 26 (1988) 113-120.

2. Tomkins, B. A., R. A. Jenkins, W. H. Greist, R. R. Reagan and S. K. Holladay: Liquid chromatographic determination of benzo[a]pyrene in total particulate matter of cigarette smoke; J. Assoc. Off. Anal. Chem. 68 (1985) 935-940. 
3. Walters, D. B., W. J. Chamberlain, M. E. Snook and O. T. Chortyk: High-pressure liquid chromatography for monitoring benzo[a]pyrene contents of cigarette smoke condensate fractions; Anal. Chem. Acta 73 (1974) 194-197.

4. Klimisch, H. J. and D. Ambrosius: Quantitative Bestimmung von Benzo[a]Pyren in Zigarettenrauchkondensaten durch HochdruckflüssigkeitsChromatographie (HPLC); Z. Anal. Chem. 280 (1976) 377-379.

5. Snook, M. E., R. F. Severson, R. F. Arrendale, H. C. Higman and O. T. Chortyk: The identification of high molecular weight polynuclear aromatic hydrocarbons in a biologically active fraction of cigarette smoke condensate; Beitr. Tabakforsch. 9 (1977) 79-101.

6. Sinclair, N. M. and B. E. Frost: Rapid method for the determination of benzo[a]pyrene in the particulate phase of cigarette smoke by high-performance liquid chromatography with fluorimetric detection; Analyst 103 (1978) 1199-1203.

7. Janini, G. M., B. Shaikh and W. L. Zielinski: Gasliquid chromatographic analysis of benzo[a]pyrene in cigarette smoke on a nematic liquid crystal; J. Chrom. 132 (1977) 136-139.

8. Ayres, C. I. and R. E. Thornton: Determination of benzo $[a]$ pyrene and related compounds in cigarette smoke; Beitr. Tabakforsch. 3 (1965) 285-290.

9. Greist, W. H., H. Kubota and M. R. Guerin: Resolution of polynuclear aromatic hydrocarbons by packed column GLC; Anal. Letters 8 (1975) 949-957.

10. Levins, R. J.: Isolation of polyaromatic hydrocarbons from whole smoke condensate: a simple two-step procedure; Chromatographia 11 (1978) 736-741.

11. Severson, R. F., W. S. Schlotzhauer, R. F. Arrendale, M. E. Snook and H. C. Higman: Correlation of polynuclear aromatic hydrocarbon formation between pyrolysis and smoking; Beitr. Tabakforsch. 9 (1977) 23-37.

12. Ellington, J. J., P. F. Schlotzhauer and A. I. Schepartz: Quantitation of tobacco lipids: analysis of serial samples of flue-cured tobacco; Proceedings of The American Chemical Society Symposium on the recent advances in the chemical composition of tobacco and tobacco smoke, New Orleans, LA, 1977, pp. 255-68.

13. Snook, M. E., P. J. Fortson and O. T. Chortyk: Isolation and identification of aza-arenes of tobacco smoke; Beitr. Tabakforsch. Int. 11 (1981) 67-78.

14. Lam, J., B. O. Pedersen and T. Thomasen: Pyrolytic disintegration of selected tobacco constituents and pyrosynthetic formation of aromatic hydrocarbons from cleavage products formed by pyrolysis; Beitr. Tabakforsch. Int. 13 (1985) 1-5.

15. Oakley, E. T., L. F. Johnson and H. M. Stahr: A rapid method for the determination of benzo[a]pyrene in cigarette smoke; Tob. Sci. 16 (1970) 19-21.
16. Klimisch, H. J. and E. Kirchheim: Eine schnelle Bestimmungsmethode für Benzo[a]Pyren, Benzo[a]Anthracen and Chrysen in Zigarettenrauch; Chromatographia 9 (1976) 119-122.

17. Hoffmann, D. and E. L. Wynder: On the isolation and identification of polycyclic aromatic hydrocarbons; Cancer 13 (1960) 1062-1073.

18. Robinson, J. L., M. A. Marshall, M. E. Draganjac and L. C. Noggle: Determination of benzo[a]pyrene in cigarette smoke condensate by liquid chromatography on Amberlite XAD-2; Anal. Chem. Acta 115 (1980) 229-238.

19. Davis, H. J., L. A. Lee and T. R. Davidson: Fluorometric determination of benzo[a]pyrene in cigarette smoke condensate; Anal. Chem. 38 (1966) 1752-1755.

20. Attiyat, A. S., G. D. Christian and J. B. Cullis: Recovery and fluorometric measurement of a polynuclear aromatic hydrocarbon from smoked cigarettes; J. Microchem. 26 (1981) 344-353.

21. Arany-Fuzessery, K. and M. Fugedi-Nemeti: Determination of benzo[a]pyrene in cigarette smoke; Acta Alimentaria 10 (1981) 329-336.

22. Pillsbury, H. C., C. C. Bright, K. J. O'Connor and F. W. Irish: Tar and nicotine in cigarette smoke; J. Assoc. Off. Anal. Chem. 52 (1969) 458-462.

23. Johnson, W. R., R. W. Hale, J. W. Nedlock, H. J. Grubbs and D. H. Powell: The distribution of products between mainstream and sidestream smoke; Tob. Sci. 17 (1973) 141-144.

24. R. J. Reynolds Tobacco Company: Chemical and biological studies on new cigarette prototypes that heat instead of burn tobacco, Winston-Salem, North Carolina 1988.

25. Klus, $H$. and $H$. Kuhn: Verteilung verschiedener Tabakrauchbestandteile auf Haupt- und Nebenstromrauch (Eine Übersicht); Beitr. Tabakforsch. Int. 11 (1982) 229-265.

\section{Acknowledgements}

The author acknowledges Doris Simmons, Marian Bowe, and Sheila Cash for the smoking of the cigarettes, and Annette Pardue for the preparation of the manuscript.

\section{Author's address}

\section{R. J. Reynolds Tobacco Company,}

Bowman Gray Technical Center, Winston-Salem, North Carolina, 27102, U.S.A. 